\title{
Regulation of the miRNA expression by TEL/AML1, BCR/ABL, MLL/AF4 and TCF3/PBX1 oncoproteins in acute lymphoblastic leukemia (Review)
}

\author{
JORGE ORGANISTA-NAVA ${ }^{1,2^{*}}$, YAZMÍN GÓMEZ-GÓMEZ ${ }^{1,2^{*}}$, \\ BERENICE ILLADES-AGUIAR ${ }^{2}$ and MARCO ANTONIO LEYVA-VÁZQUEZ ${ }^{2}$ \\ ${ }^{1}$ Institute of Cellular Physiology, National Autonomous University of Mexico (UNAM), University City, D.F.; \\ ${ }^{2}$ Laboratory of Molecular Biomedicine, School of Chemical-Biological Sciences, \\ Guerrero State University, Chilpancingo, Guerrero, Mexico
}

Received February 13, 2016; Accepted March 28, 2016

DOI: $10.3892 /$ or.2016.4948

\begin{abstract}
MicroRNAs (miRNAs) are a class of small endogenous non-coding RNAs that play important regulatory roles by targeting mRNAs for cleavage or translational repression. miRNAs act in diverse biological processes including development, cell growth, apoptosis, and hematopoiesis. The miRNA expression is associated with specific cytogenetic changes and can also be used to discriminate between the different subtypes of leukemia in acute lymphoblastic leukemia with common translocations, it is shown that the miRNAs have the potential to be used for clinical diagnosis and prognosis. We reviewed the roles of miRNA here with emphasis on their function in human leukemia and the mechanisms of the TEL/AML1, BCR/ABL, MLL/AF4 and TCF3/PBX1 oncoproteins on miRNAs expression in acute lymphoblastic leukemia.
\end{abstract}

\section{Contents}

1. Introduction

2. miRNA expression and oncoproteins in acute lymphoblastic leukemia

3. miRNAs in diagnosis and prognosis of ALL

4. Conclusions

Correspondence to: Dr Jorge Organista-Nava or Dr Marco Antonio Leyva-Vázquez, Laboratory of Molecular Biomedicine, School of Biological Sciences, Guerrero State University, Av. Lázaro Cárdenas S/N, Ciudad Universitaria, Chilpancingo, Guerrero 39090, México

E-mail: joorna@gmail.com

E-mail: leyvamarco13@gmail.com

${ }^{*}$ Contributed equally

Key words: acute lymphoblastic leukemia, miRNAs, TEL/AML1, BCR/ABL, MLL/AF4, E2A/PBX1

\section{Introduction}

Leukemia is a malignancy of the hematopoietic system characterized by diffuse replacement of the bone marrow by neoplastic cells (1). Acute lymphoid leukemia (ALL) and acute myeloid leukemia (AML) are oncohematologic diseases in which the process of differentiation and limited proliferation that characterizes normal hematopoiesis is altered and replaced by a malignant clonal expansion of immature hematopoietic cells (blasts) in the bone marrow or peripheral blood (2-5).

Epidemiological studies indicate that the annual incidence rates of childhood ALL vary worldwide between one and four new cases per 100,000 children younger than 15 years, with a peak incidence at approximately 2-5 years of age (6-8), whereas AML has been observed with an incidence of 3.7 per 100,000 persons and an age-dependent mortality of 2.7 to nearly 18 per 100,000 persons (9).

Abnormalities in chromosome number as well as structural rearrangements (translocations) are detected in 60-80\% of patients with ALL, whereas the remaining 20-40\% have a normal karyotype (9-14). In addition to those with a normal karyotype, $\mathrm{t}(12 ; 21)(\mathrm{p} 13 ; \mathrm{q} 22) ; \mathrm{TEL} / \mathrm{AML1}$ (ETV6-RUNX1), $\mathrm{t}(9 ; 22)(\mathrm{q} 34, \mathrm{q} 11)$; BCR/ABL (BCR-ABL1), t(4;11) (q21;q23); MLL/AF4 (KMT2A/AFF1), t(1;19)(q23;p13); E2A/PBX1 (TCF3-PBX1), are among the most common cytogenetic subtypes in ALL (10-12,14), and have been incorporated in the World Health Organization (WHO) classification as the criteria for subclassification of acute leukemia (15).

ALL can be distinguished from AML using morphologic, immunohistochemical, and immunologic methods (16). The study by Golub et al showed that the gene expression profiles can discriminate the ALL from AML (17). However, the precise genes and pathways that exert critical control over determination of lineage fate during leukemia development remain unclear (18).

Hematopoiesis is a highly regulated process of the differentiation, proliferation hematopoietic stem cells give rise to all the blood lineages: the myeloid lineage, which comprises neutrophils, eosinophils, basophils, monocytes, macrophages, 
Table I. Expression of miRNAs in rearrangement-positive ALL.

\begin{tabular}{|c|c|c|c|}
\hline miRNAs & Function in cancer ${ }^{\mathrm{a}}$ & Expression & Authors/(Ref.) \\
\hline \multicolumn{4}{|c|}{ TEL/AML1-positive rearrangement } \\
\hline $\operatorname{miR}-26 b$ & OG/TSG & Downregulation & Diakos et al (28) \\
\hline miR-320a & TSG & & \\
\hline $\operatorname{miR}-494$ & TSG & & \\
\hline miR-213 & TSG & Downregulation & \\
\hline miR-221 & OG/TSG & & \\
\hline miR-99a & OG & Upregulation & Schotte et al (27) \\
\hline $\operatorname{miR}-100$ & OG/TSG & & \\
\hline $\operatorname{miR}-125 b$ & OG & & \\
\hline $\operatorname{miR}-126$ & OG/TSG & & \\
\hline miR-383 & OG/TSG & & \\
\hline $\operatorname{miR}-629$ & OG & & \\
\hline $\operatorname{miR}-125 b$ & OG & Upregulation & Gefen et al (29) \\
\hline \multicolumn{4}{|c|}{ BCR/ABL-positive rearrangement } \\
\hline miR-17 & OG & Upregulation & Scherr et al (33) \\
\hline miR-18 & OG & & \\
\hline miR-19a & OG & & \\
\hline miR-20a & OG & & \\
\hline miR-93 & OG & Downregulation & Schotte et al (27) \\
\hline miR-103 & OG/TSG & & \\
\hline $\operatorname{miR}-148 b$ & TSG & & \\
\hline $\operatorname{miR}-210$ & OG/TSG & & \\
\hline miR-301 & TSG & & \\
\hline miR-331 & TSG & & \\
\hline $\operatorname{miR}-345$ & OG/TSG & & \\
\hline $\operatorname{miR}-484$ & TSG & & \\
\hline $\operatorname{miR}-1226$ & TSG & & \\
\hline \multicolumn{4}{|c|}{ MLL/AF4-positive rearrangement } \\
\hline Let-7b & TSG & Downregulation & Mi et al (18) \\
\hline miR-128a & OG/TSG & Upregulation & \\
\hline $\operatorname{miR}-128 b$ & OG/TSG & & \\
\hline $\operatorname{miR}-128 \mathrm{a}$ & OG/TSG & Upregulation & Oliveira et al (47) \\
\hline $\operatorname{miR}-128 b$ & OG/TSG & & \\
\hline $\operatorname{miR}-181 b$ & OG & & \\
\hline $\operatorname{miR}-143$ & TSG & Downregulation & Dou et al (46) \\
\hline $\operatorname{mir}-196 b$ & OG & Upregulation & $\begin{array}{l}\text { Popovic et al (50) } \\
\text { and Li et al (51) }\end{array}$ \\
\hline \multicolumn{4}{|c|}{ TCF3/PBX1-positive rearrangement } \\
\hline miR-24 & OG/TSG & Downregulation & Schotte et al (27) \\
\hline miR-126 & OG/TSG & & \\
\hline $\operatorname{miR}-146 a$ & TSG & & \\
\hline $\operatorname{miR}-193 a$ & TSG & & \\
\hline miR-365 & TSG & & \\
\hline miR-511 & TSG & & \\
\hline $\operatorname{miR}-545$ & TSG & & \\
\hline miR-181 & OG & Upregulation & Schotte et al (56) \\
\hline miR-708 & OG & & \\
\hline $\operatorname{mir}-196 b$ & TSG & Downregulation & \\
\hline
\end{tabular}




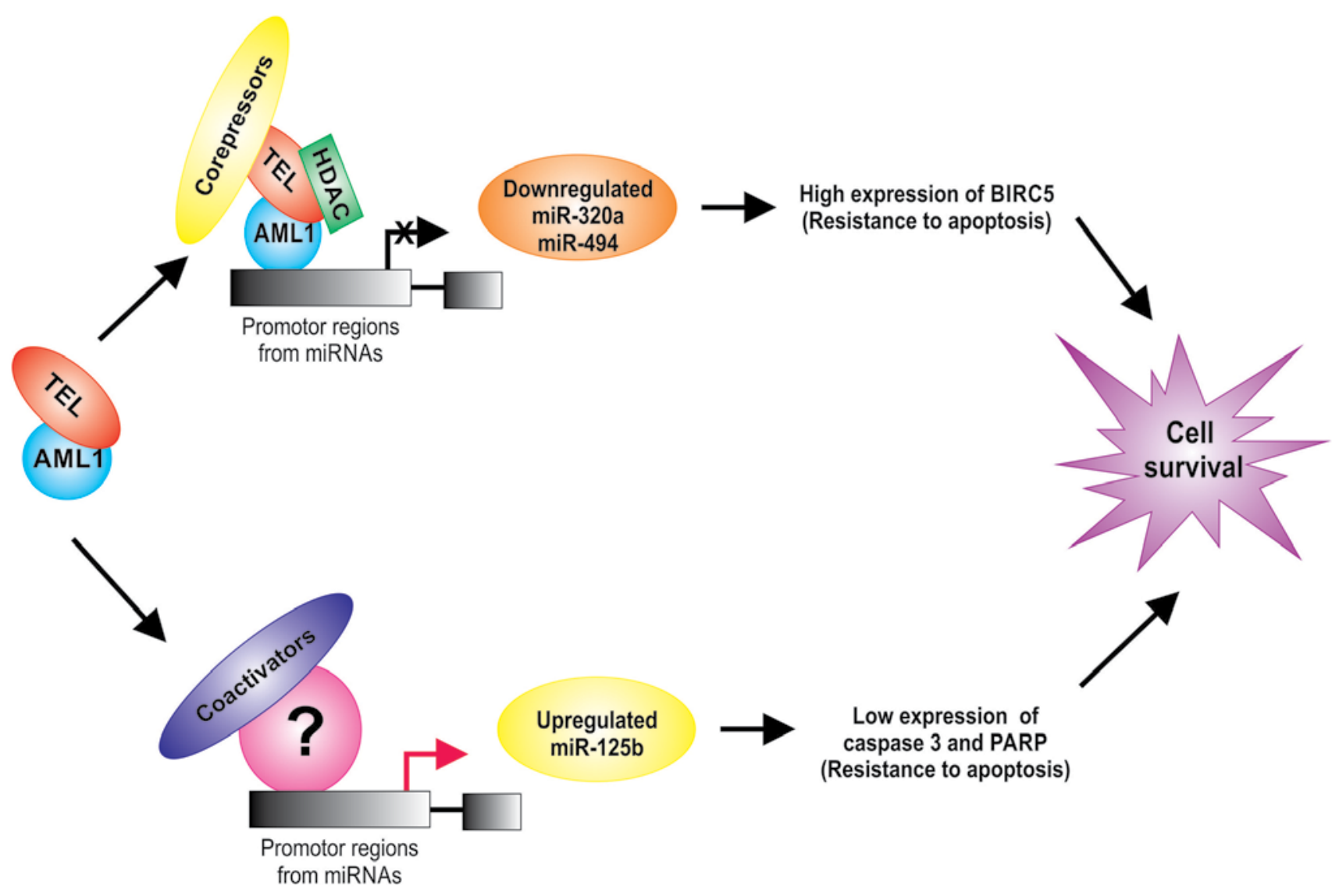

Figure 1. TEL/AML oncoprotein in the regulation of miR-320a and miR-494 and cellular processes affected in ALL. TEL, transcription factor ETV6; AML, acute myeloid leukemia 1 protein; ALL, acute lymphoblastic leukemia.

megakaryocytes, platelets and erythrocytes; and the lymphoid lineage, which includes T and B cells $(19,20)$.

The process is modulated by a series of molecular events, and there is increasing evidence that miRNAs have important roles in modulating hematopoietic process by targeting the expression of transcription factors and genes that are involved in the regulation of cell proliferation, metabolism, and apoptosis (21). Aberrant expression of many different miRNAs has been observed in several cancers, including hematological malignancies. Furthermore, approximately $50 \%$ of miRNAs are located at fragile sites and genomic regions in the human genome associated with cancer (22). In this review, we summarized the association of the miRNA expression with chromosomal translocations in acute leukemia, with a specific focus on acute lymphoblastic leukemia.

\section{2. miRNA expression and oncoproteins in acute lympho- blastic leukemia}

TEL/AML1; $t(12 ; 21)(p 13 ; q 22)$. TEL/AML1 t(12;21) (p13;q22) fusion gene, resulting from 12;21 chromosomal translocation, is believed to be the most common molecular genetic abnormality in childhood acute lymphoblastic leukemia (23). The resulting fusion protein has the AML1 DNA binding domain and the TEL protein interaction domain and has been shown to maintain transcription factor properties and bind DNA $(24,25)$. TEL/AML1 act as a transcription factor that reduce the expression of tumor suppressor and increase antiapoptotic genes (26) and also alters the regulation of miRNA expression $(27,28)$ (Table I). For example, the miR-320a and miR-498 tumor suppressor are significantly lower in TEL/AML1positive acute lymphoblastic leukemias (28). Interestingly, these miRNAs can inhibit the expression of survivin in leukemia cells, inducing apoptosis, suggests that miR-320a and miR-498 are potential tumor suppressors or miRNAs that may play a critical role in the leukemic process (28). The TEL/AML1 protein is generally a transcriptional repressor due to its known ability to recruit chromatin repressors such as histone deacetylases, nuclear receptor corepressors (Fig. 1).

Other upregulation miRNAs in TEL/AML1-positive acute lymphoblastic leukemias have also been reported (27-29) and it has been observed that AML1 can associate with coactivators to regulate the promoters of its target genes (30). For example, miR-125b is an oncogenic miRNA by its anti-apoptotic activity which is associated with a marked inhibition of caspase 3 activation and the cleavage of its substrate PARP (29), suggesting an active role for miR-125b in the leukemogenesis (31) and its expression is an independent event from TEL/AML1 protein (Fig. 1).

$B C R / A B L 1 ; t(9 ; 22)(q 34, q 11)$. BCR/ABL1 or Philadelphia $(\mathrm{Ph})$ chromosome is a product of the $\mathrm{t}(9 ; 22)$, which fuses the Abelson kinase gene (ABL1) from chromosome 9 with the breakpoint cluster region (BCR) from chromosome 22 that expresses the BCR-ABL1 fusion protein: a constitutively active tyrosine kinase. The BCR/ABL1 fusion protein is a hallmark present in 


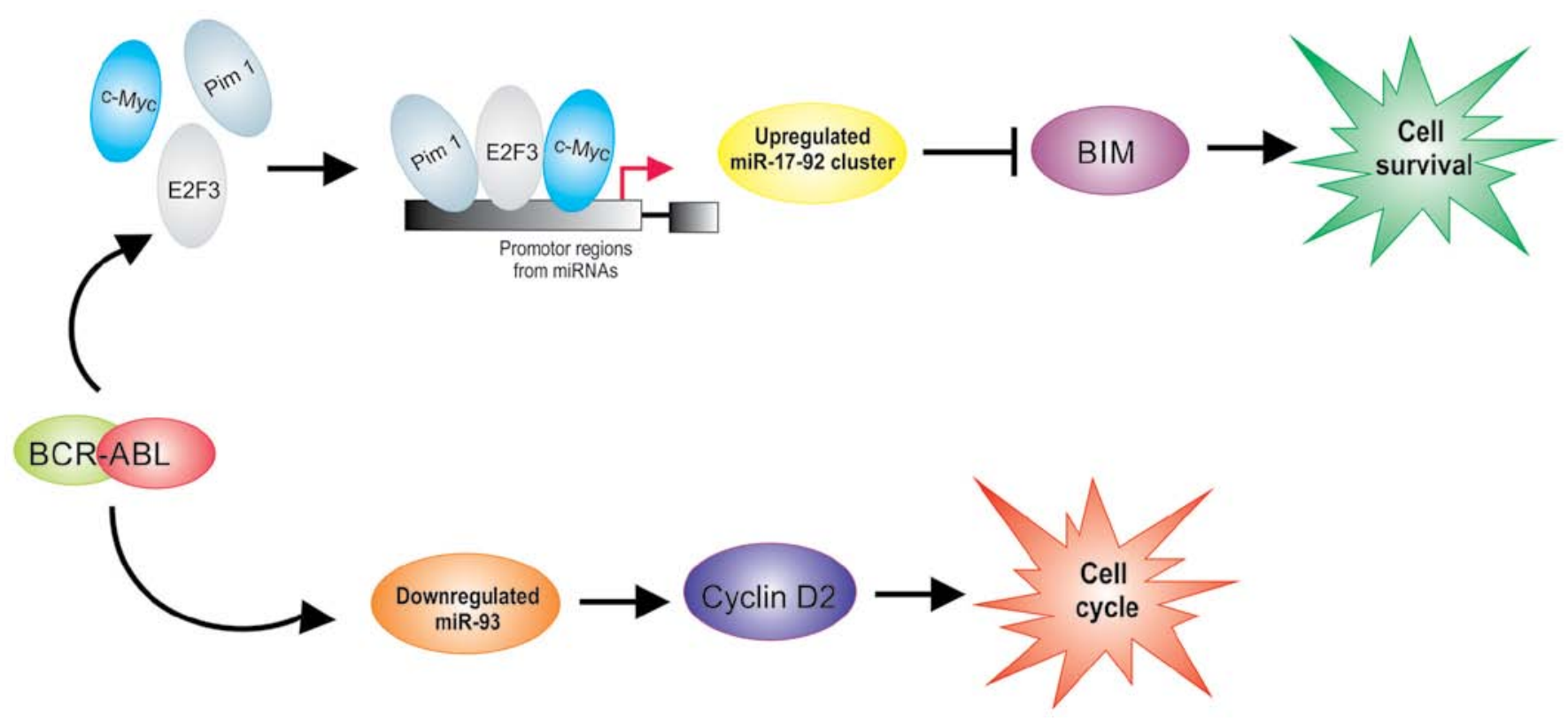

Figure 2. BCR/ABL oncoprotein in the regulation of miR-17-92 cluster and miR-93 and cellular processes affected in ALL. BCR, breakpoint cluster region protein; ABL, abelson murine leukemia viral oncogene homolog; ALL, acute lymphoblastic leukemia.

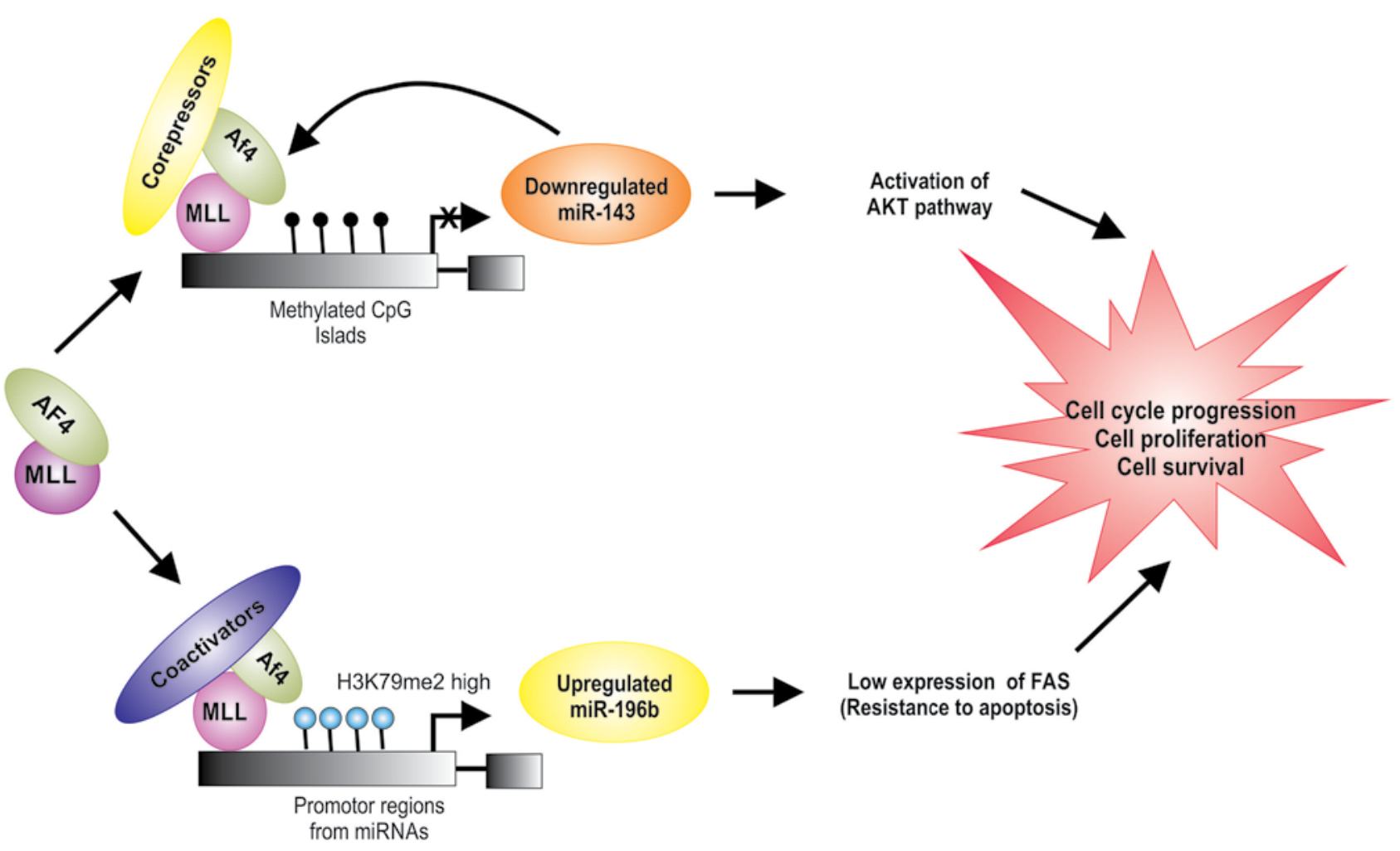

Figure 3. AF4/MLL oncoprotein in the regulation of miR-143 and miR-125b and cellular processes affected in ALL. AF4, AF4/FMR2 family member 1; MLL, mixed lineage leukemia; ALL, acute lymphoblastic leukemia.

a fraction of B progenitor ALL cases that have a particularly poor prognosis (32).

Several miRNAs are overexpressed in BCR/ABL1-positive ALL $(27,33)$ (Table I). BCR/ABL has been shown to upregulate Pim-1 (34,35), E2F3 (36) and c-Myc (35) who regulate the transcriptional expression of miR-17-92 clusters. Recently, it was reported that BIM, a proapoptotic member, is a direct target of miR-17-92 clusters (37). It was demonstrated that BIM is poorly expressed in ALL (38), while the members of the miR-17-92 clusters that have been reported to be upregulated in BCR/ABL1-positive ALL (33). These data demonstrate that the upregulation of miR-17-92 cluster expression observed in BCR/ABL1-positive ALL could have an important role in survival of cells in leukemia (Fig. 2). 
Interestingly, a direct relationship between $\mathrm{BCR} / \mathrm{ABL}$ activity and cyclin D2 expression in BCR/ABL-positive cells has been demonstrated $(39,40)$; these reports suggest the importance of cyclin D2 in mediating the proliferative signals from $\mathrm{BCR} / \mathrm{ABL}$ and show that $\mathrm{BCR} / \mathrm{ABL}$ regulates cyclin $\mathrm{D} 2$ expression at the transcriptional level. A recent study showed that miR-93 is downregulated in BCR/ABL-positive patients (27). Interestingly, this miRNA can inhibit the expression of cyclin D2 which leads to cell cycle progression (41). Overexpression of cyclins D2 in BCR/ABL-positive hematopoietic cell have been reported $(39,40)$. The abnormal expression of cyclin D2 may influence the initiation of tumorigenesis, including leukemogenesis (42), suggesting that downregulation of miR-93 could be involved to the leukemogenesis at least partly via upregulation of cyclin D2 expression in BCR/ABL-positive cells (Fig. 2).

MLL/AF4; $t(4 ; 11)(q 21 ; q 23)$. The $\mathrm{t}(4 ; 11)(\mathrm{q} 21 ; \mathrm{q} 23)$ involving the genes MLL and AF4 (alias for AFF1) is detected in 50-70\% of infant leukemia. MLL/AF4, an MLL fusion protein that is associated with infant pro-B acute lymphoblastic leukemias (43), and it is usually associated with a poor prognosis (44). Rearrangements of the MLL gene result in a fusion protein that retain the DNA binding capacities, the CXXC domain, which binds to non-methylated CpG DNA sites, as well as their DNA methyltransferase activity (transcriptional activation/ repression domain of MLL), it is possible that the MLL-fusion proteins directly regulate a subset of genes (45).

Recent studies indicate that MLL/AF4 regulates the expression of miRNas (Table I), which can play a role in leukemogenesis by stimulating proliferation and inducing a block in differentiation of hematopoietic cells $(46,47)$. Dou et al demonstrated that the expression levels of miR-143 are significantly lower in MLL-AF4-positive cells (46). PI3K/ $\mathrm{AKT} / \mathrm{mTOR}$ is a survival pathway and plays an important role in cell proliferation, differentiation and apoptosis. Its abnormal activation has been found in cases of MLL/AF4-positive ALL (48). miR-143 has been shown to decrease the level of Akt at translational level (49). miR-143 is epigenetically repressed by promoter hypermethylation in MLL/AF4-positive primary blasts and cell lines, which was directly associated with expression of the MLL/AF4 oncogene (46). Additionally, it was shown that MLL/AF4 is a target for miR-143, and that DNA methylation decreases the expression of miR-143 in MLL/AF4-positive ALL (46), it is possible that the MLL/AF4 proteins directly downregulate the miR143 expression by the DNA methyltransferase activity of MLL (Fig. 3).

miR-196b is an oncogene and appears to be required for MLL/AF4-mediated cell transformation and it was reported that miR-196b is upregulated in MLL/AF4-positive cell lines (50). MLL/AF4 protein regulate the transcriptional expression of miR-196b by increasing levels of K79me2 on the promoter of miR-196b $(50,51)$. FAS plays a central role in the physiological regulation of apoptosis (52), and it has been implicated in the leukemogenesis (51). FAS is direct target of miR-196b and is negatively regulated at the mRNA and protein levels (51). It was demonstrated that FAS is poorly expressed in MLL/ AF4-positive human leukemic cells, compared to the normal cells (Table I) $(50,51)$. Li et al found that the low expression of FAS leads to inhibition of FAS-mediated apoptosis (51). These data demonstrate that the upregulation of miR-196b expression observed in MLL/AF4-positive cell has an important role in cell survival in leukemia by targeting FAS mRNA in MLL/ AF4-positive cells (Fig. 3).

TCF3/PBX1; $t(1 ; 19)(q 23 ; p 13)$. The $\mathrm{t}(1 ; 19)(\mathrm{q} 23 ; \mathrm{p} 13)$ is one of the most frequent translocations in B-acute lymphoblastic leukemia (B-ALL), and is observed in both adult and pediatric populations at an overall frequency of $6 \%$ (53). This translocation is the result from the fusion of TCF3 (transcription factor 3) found at 19p13 and PBX1 (pre-B cell leukemia homebox 1) found at 1q23 forming a chimeric gene whose protein product alters cell differentiation arrest, among other cellular processes (54). TCF3/PBX1 encodes a transcription factor bearing the transactivation domain of TCF3 and the DNA-binding domain of PBX1, which facilitates the activation or repression of genes (55).

Several miRNAs are downregulated or upregulated in TCF3/PBX1-positive ALL $(27,56)$ (Table I). For example, miR-126 plays a pivotal role in restraining cell cycle progression of hematopoietic stem cell in vitro and in vivo, it was observed that the downregulation of this miRNA resulted in cell cycle progression and hematopoietic stem cell expansion (57). miR-126 is significantly lower expressed in TCF3/ PBX1-ALL and was shown to correlate with in vitro resistance to vincristine and daunorubicin in childhood ALL (27). This suggests that miR-126 may have potential in prognosis prediction and therapeutic application in ALL patients.

\section{3. miRNAs in diagnosis and prognosis of ALL}

MicroRNAs are associated with the regulation of normal hematopoiesis and their disruption has been related to many types of cancer, including hematological malignancies. Pediatric ALL samples showed lower expression levels of miR-100, miR-196b and let-7e, while miR-128a and miR-181b were overexpressed compared to normal pediatric samples (47). miR-451 and miR-373 were downregulated, while an increase in miR-222, mIR-339 and miR-142-3p was identified in pre-B-ALL cells compared to control $\mathrm{CD} 19^{+}(58)$. It is also possible to identify between different ALL subtypes (B-ALL and T-ALL) using miRNA signatures: miR-151 (downregulated in T-ALL), miR148a and miR-424 (both highly expressed in T-ALL) could all be used to discriminate between these two leukemic subtypes $(59,60)$. Furthermore, it is possible to distinguish between B-ALL subtypes using miRNA expression, as exemplified by miR-629 having high expression in MLL-AF4, miR-425-5p miR-191 and miR-128 being highly expressed in E2A-PBX1. BCR-Abl also generates higher expression of miR-146b and miR-126 (59).

Prognosis can be tested by miRNA expression. miR-708 was upregulated in relapse, whereas both miR-223 and miR-27a were highly expressed in patients during remission, suggesting that these dysregulated miRNAs play important roles in controlling disease (61). It also was reported that vincristine-resistant ALL patients expressed higher levels of miR-125b (27). The miR-10a, miR-134 and miR-214 expression was linked to a favorable outcome in pediatric ALL, while the expression of miR-33 was associated with an unfavorable prognosis in T-ALL compared to in normal thymocytes (27). 


\section{Conclusions}

The discovery of miRNAs and their association with TEL/ AML1, BCR/ABL, MLL/AF4, E2A/PBX1 oncoproteins in acute lymphoblastic leukemia have provided valuable information on potential diagnostic and/or prognostic biomarkers, as well as monitoring the disease progression. Moreover, a potential role of the microRNAs has been suggested in specific subtypes of acute lymphoblastic leukemia and in the development of different phenotypes. Also it is noted that the changes of miRNA expression levels may play an important role in the genesis and evolution of acute lymphoblastic leukemia. Thus, the mechanism of miRNA regulation by TEL/AML1, BCR/ ABL, MLL/AF4, E2A/PBX1 oncoproteins is very complex. Studies are needed to clearly demonstrate the effect of miRNAs in leukemogenesis and its practical implications.

\section{Acknowledgements}

J.O.N and Y.G.G. were recipients of fellowships from the Programa de Apoyo a los Estudios de Posgrado, Universidad Nacional Autónoma de Mexico (PAEP-UNAM).

\section{References}

1. Cartwright RA, Alexander FE, McKinney PA and Ricketts TJ: Leukaemia and lymphoma. An atlas of distribution within areas of England and Wales 1984-1988. Stat Med 11: 135-136, 1992.

2. Graubert TA and Mardis ER: Genomics of acute myeloid leukemia. Cancer J 17: 487-491, 2011.

3. Greaves M: Infection, immune responses and the aetiology of childhood leukaemia. Nat Rev Cancer 6: 193-203, 2006.

4. Greaves MF: Aetiology of acute leukaemia. Lancet 349: 344-349, 1997.

5. Miller DR and Miller LP: Acute lymphoblastic leukemia in children: An update of clinical, biological, and therapeutic aspects. Crit Rev Oncol Hematol 10: 131-164, 1990.

6. Redaelli A, Laskin BL, Stephens JM, Botteman MF and Pashos CL: A systematic literature review of the clinical and epidemiological burden of acute lymphoblastic leukaemia (ALL). Eur J Cancer Care (Engl) 14: 53-62, 2005.

7. Linabery AM and Ross JA: Trends in childhood cancer incidence in the U.S. (1992-2004). Cancer 112: 416-432, 2008.

8. Howard SC, Metzger ML, Wilimas JA, Quintana Y, Pui CH, Robison LL and Ribeiro RC: Childhood cancer epidemiology in low-income countries. Cancer 112: 461-472, 2008.

9. Deschler B and Lübbert M: Acute myeloid leukemia: Epidemiology and etiology. Cancer 107: 2099-2107, 2006.

10. Look AT: Oncogenic transcription factors in the human acute leukemias. Science 278: 1059-1064, 1997.

11. Pui C-H and Jeha S: New therapeutic strategies for the treatment of acute lymphoblastic leukaemia. Nat Rev Drug Discov 6 : 149-165, 2007.

12. Rowley JD: Chromosome translocations: Dangerous liaisons revisited. Nat Rev Cancer 1: 245-250, 2001

13. Haferlach T, Bacher U, Kern W, Schnittger S and Haferlach C: Diagnostic pathways in acute leukemias: A proposal for a multimodal approach. Ann Hematol 86: 311-327, 2007.

14. Armstrong SA and Look AT: Molecular genetics of acute lymphoblastic leukemia. J Clin Oncol 23: 6306-6315, 2005.

15. Steven HS, Swerdlow EC, Harris NL, et al: International WHO classification of tumours of haematopoietic and lymphoid tissues. Agency for Research on Cancer, Lyon, pp274-288, 2008.

16. Löwenberg B, Downing JR and Burnett A: Acute myeloid leukemia. N Engl J Med 341: 1051-1062, 1999.

17. Golub TR, Slonim DK, Tamayo P, Huard C, Gaasenbeek M, Mesirov JP, Coller H, Loh ML, Downing JR, Caligiuri MA, et al: Molecular classification of cancer: Class discovery and clas prediction by gene expression monitoring. Science 286: 531-537, 1999.
18. Mi S, Lu J, Sun M, Li Z, Zhang H, Neilly MB, Wang Y, Qian Z, Jin J, Zhang Y, et al: MicroRNA expression signatures accurately discriminate acute lymphoblastic leukemia from acute myeloid leukemia. Proc Natl Acad Sci USA 104: 19971-19976, 2007.

19. Iwasaki $\mathrm{H}$ and Akashi $\mathrm{K}$ : Hematopoietic developmental pathways: On cellular basis. Oncogene 26: 6687-6696, 2007.

20. Doulatov S, Notta F, Laurenti E and Dick JE: Hematopoiesis: A human perspective. Cell Stem Cell 10: 120-136, 2012.

21. Sun K and Lai EC: Adult-specific functions of animal microRNAs. Nat Rev Genet 14: 535-548, 2013.

22. Calin GA, Sevignani C, Dumitru CD, Hyslop T, Noch E, Yendamuri S, Shimizu M, Rattan S, Bullrich F, Negrini M, et al: Human microRNA genes are frequently located at fragile sites and genomic regions involved in cancers. Proc Natl Acad Sci USA 101: 2999-3004, 2004.

23. Jamil A, Theil KS, Kahwash S, Ruymann FB and Klopfenstein KJ: TEL/AML-1 fusion gene. its frequency and prognostic significance in childhood acute lymphoblastic leukemia. Cancer Genet Cytogenet 122: 73-78, 2000.

24. Golub TR, McLean T, Stegmaier K, Carroll M, Tomasson M and Gilliland DG: The TEL gene and human leukemia. Biochim Biophys Acta 1288: M7-M10, 1996.

25. Lorsbach RB and Downing JR: The role of the AML1 transcription factor in leukemogenesis. Int J Hematol 74: 258-265, 2001.

26. Krug U, Ganser A and Koeffler HP: Tumor suppressor genes in normal and malignant hematopoiesis. Oncogene 21: 3475-3495, 2002.

27. Schotte D, De Menezes RX, Akbari Moqadam F, Khankahdani LM, Lange-Turenhout E, Chen C, Pieters R and Den Boer ML: MicroRNA characterize genetic diversity and drug resistance in pediatric acute lymphoblastic leukemia. Haematologica 96: 703-711, 2011.

28. Diakos C, Zhong S, Xiao Y, Zhou M, Vasconcelos GM, Krapf G, Yeh RF, Zheng S, Kang M, Wiencke JK, et al: TEL-AML1 regulation of survivin and apoptosis via miRNA-494 and miRNA-320a. Blood 116: 4885-4893, 2010.

29. Gefen N, Binder V, Zaliova M, Linka Y, Morrow M, Novosel A, Edry L, Hertzberg L, Shomron N, Williams O, et al: Hsa-mir125b-2 is highly expressed in childhood ETV6/RUNX1 (TEL/ AML1) leukemias and confers survival advantage to growth inhibitory signals independent of p53. Leukemia 24: 89-96, 2010.

30. Zelent A, Greaves M and Enver T: Role of the TEL-AML1 fusion gene in the molecular pathogenesis of childhood acute lymphoblastic leukaemia. Oncogene 23: 4275-4283, 2004.

31. Bousquet M, Harris MH, Zhou B and Lodish HF: MicroRNA miR-125b causes leukemia. Proc Natl Acad Sci USA 107: 21558-21563, 2010.

32. Faber J, Gregory RI and Armstrong SA: Linking miRNA regulation to BCR-ABL expression: The next dimension. Cancer Cell 13: 467-469, 2008.

33. Scherr M, Elder A, Battmer K, Barzan D, Bomken S, RickeHoch M, Schröder A, Venturini L, Blair HJ, Vormoor J, et al: Differential expression of miR-17 92 identifies BCL2 as a therapeutic target in BCR-ABL-positive B-lineage acute lymphoblastic leukemia. Leukemia 28: 554-565, 2014.

34. Nieborowska-Skorska M, Hoser G, Kossev P, Wasik MA and Skorski T: Complementary functions of the antiapoptotic protein $\mathrm{A} 1$ and serine/threonine kinase pim-1 in the BCR/ABL-mediated leukemogenesis. Blood 99: 4531-4539, 2002.

35. Thomas M, Lange-Grünweller K, Hartmann D, Golde L, Schlereth J, Streng D, Aigner A, Grünweller A and Hartmann RK: Analysis of transcriptional regulation of the human miR-17-92 cluster; evidence for involvement of Pim-1. Int J Mol Sci 14: 12273-12296, 2013.

36. Eiring AM, Neviani P, Santhanam R, Oaks JJ, Chang JS, Notari M, Willis W, Gambacorti-Passerini C, Volinia S, Marcucci G, et al: Identification of novel posttranscriptional targets of the $\mathrm{BCR} / \mathrm{ABL}$ oncoprotein by ribonomics: Requirement of E2F3 for BCR/ABL leukemogenesis. Blood 111: 816-828, 2008.

37. Mogilyansky E and Rigoutsos I: The miR-17/92 cluster: A comprehensive update on its genomics, genetics, functions and increasingly important and numerous roles in health and disease. Cell Death Differ 20: 1603-1614, 2013.

38. Jiang N, Koh GS, Lim JY, Kham SK, Ariffin H, Chew FT and Yeoh AE: BIM is a prognostic biomarker for early prednisolone response in pediatric acute lymphoblastic leukemia. Exp Hematol 39: 321-329, 329.e1-329.e3, 2011. 
39. Deininger MW, Vieira SA, Parada Y, Banerji L, Lam EW, Peters G, Mahon FX, Köhler T, Goldman JM and Melo JV: Direct relation between BCR-ABL tyrosine kinase activity and cyclin D2 expression in lymphoblasts. Cancer Res 61: 8005-8013, 2001.

40. Parada Y, Banerji L, Glassford J, Lea NC, Collado M, Rivas C, Lewis JL, Gordon MY, Thomas NS and Lam EW: BCR-ABL and interleukin 3 promote haematopoietic cell proliferation and survival through modulation of cyclin D2 and p27Kip1 expression. J Biol Chem 276: 23572-23580, 2001.

41. Yu X-F, Zou J, Bao Z-J and Dong J: miR-93 suppresses proliferation and colony formation of human colon cancer stem cells. World J Gastroenterol 17: 4711-4717, 2011.

42. Ohtsubo M and Roberts JM: Cyclin-dependent regulation of G1 in mammalian fibroblasts. Science 259: 1908-1912, 1993.

43. Johansson B, Moorman AV, Haas OA, Watmore AE, Cheung KL, Swanton S and Secker-Walker LM: Hematologic malignancies with $\mathrm{t}(4 ; 11)(\mathrm{q} 21 ; \mathrm{q} 23)$ - a cytogenetic, morphologic, immunophenotypic and clinical study of 183 cases. European 11q23 Workshop participants. Leukemia 12: 779-787, 1998.

44. Behm FG, Raimondi SC, Frestedt JL, Liu Q, Crist WM, Downing JR, Rivera GK, Kersey JH and Pui CH: Rearrangement of the MLL gene confers a poor prognosis in childhood acute lymphoblastic leukemia, regardless of presenting age. Blood 87: 2870-2877, 1996.

45. Tamai $\mathrm{H}$ and Inokuchi K: 11q23/MLL acute leukemia: Update of clinical aspects. J Clin Exp Hematop 50: 91-98, 2010.

46. Dou L, Zheng D, Li J, Li Y, Gao L, Wang L and Yu L: Methylation-mediated repression of microRNA-143 enhances MLL-AF4 oncogene expression. Oncogene 31: 507-517, 2012.

47. de Oliveira JC, Scrideli CA, Brassesco MS, Morales AG, Pezuk JA, Queiroz RP, Yunes JA, Brandalise SR and Tone LG: Differential miRNA expression in childhood acute lymphoblastic leukemia and association with clinical and biological features. Leuk Res 36: 293-298, 2012

48. Urtishak KA, Li-San W, Teachey DT, Sarah TK, Barrett JS, Chen I-ML, Atlas SR, Harvey RC, Heerema NA, Carroll AJ, et al: $\mathrm{PI} 3 \mathrm{~K} / \mathrm{AKT} / \mathrm{mTOR}$ signaling is a significant druggable pathway in infant acute lymphoblastic leukemia. Blood 122: $1669,2013$.

49. Noguchi S, Mori T, Hoshino Y, Maruo K, Yamada N, Kitade Y, Naoe T and Akao Y: MicroRNA-143 functions as a tumor suppressor in human bladder cancer T24 cells. Cancer Lett 307: 211-220, 2011.

50. Popovic R, Riesbeck LE, Velu CS, Chaubey A, Zhang J, Achille NJ, Erfurth FE, Eaton K, Lu J, Grimes HL, et al: Regulation of mir-196b by MLL and its overexpression by MLL fusions contributes to immortalization. Blood 113: 3314-3322, 2009.
51. Li Z, Huang H, Chen P, He M, Li Y, Arnovitz S, Jiang X, He C, Hyjek E, Zhang J, et al: miR-196b directly targets both HOXA9/MEIS1 oncogenes and FAS tumour suppressor in MLL-rearranged leukaemia. Nat Commun 3: 688, 2012.

52. Itoh N, Yonehara S, Ishii A, Yonehara M, Mizushima S, Sameshima M, Hase A, Seto Y and Nagata S: The polypeptide encoded by the cDNA for human cell surface antigen Fas can mediate apoptosis. Cell 66: 233-243, 1991.

53. Tirado CA, Shabsovich D, Yeh L, Pullarkat ST, Yang L, Kallen M and Rao N: A $(1 ; 19)$ translocation involving TCF3-PBX1 fusion within the context of a hyperdiploid karyotype in adult B-ALL: A case report and review of the literature. Biomark Res 3: 4, 2015.

54. Heim S and Mitelman F (eds): Cancer Cytogenetics. 3. Wiley Online Library, Hoboken, NJ, 2009.

55. Hajingabo LJ, Daakour S, Martin M, Grausenburger R, PanzerGrümayer R, Dequiedt F, Simonis N and Twizere JC: Predicting interactome network perturbations in human cancer: Application to gene fusions in acute lymphoblastic leukemia. Mol Biol Cell 25: 3973-3985, 2014

56. Schotte D, Chau JCK, Sylvester G, Liu G, Chen C, van der Velden VH, Broekhuis MJ, Peters TC, Pieters R and den Boer ML: Identification of new microRNA genes and aberrant microRNA profiles in childhood acute lymphoblastic leukemia. Leukemia 23: 313-322, 2009.

57. Lechman ER, Gentner B, van Galen P, Giustacchini A, Saini M, Boccalatte FE, Hiramatsu H, Restuccia U, Bachi A, Voisin V, et al: Attenuation of miR-126 activity expands HSC in vivo without exhaustion. Cell Stem Cell 11: 799-811, 2012.

58. Ju X, Li D, Shi Q, Hou H, Sun N and Shen B: Differential microRNA expression in childhood B-cell precursor acute lymphoblastic leukemia. Pediatr Hematol Oncol 26: 1-10, 2009.

59. Fulci V, Colombo T, Chiaretti S, Messina M, Citarella F, Tavolaro S, Guarini A, Foà R and Macino G: Characterization of B- and T-lineage acute lymphoblastic leukemia by integrated analysis of MicroRNA and mRNA expression profiles. Genes Chromosomes Cancer 48: 1069-1082, 2009.

60. Saki N, Abroun S, Soleimani M, Hajizamani S, Shahjahani M, Kast RE and Mortazavi Y: Involvement of microRNA in T-cell differentiation and malignancy. Int J Hematol Oncol Stem Cell Res 9: 33-49, 2015.

61. Han B-W, Feng D-D, Li Z-G, Luo XQ, Zhang H, Li XJ, Zhang XJ, Zheng LL, Zeng CW, Lin KY, et al: A set of miRNAs that involve in the pathways of drug resistance and leukemic stem-cell differentiation is associated with the risk of relapse and glucocorticoid response in childhood ALL. Hum Mol Genet 20: 4903-4915, 2011 